\title{
Effect of climate change on thermal-ice regime of shallow lakes compared to deep lakes: Case study of lakes in the temperate zone (Northern Poland)
}

\author{
Włodzimierz MARSZELEWSKI, ${ }^{*}$ Bożena PIUS
}

Nicolaus Copernicus University in Toruń, Faculty of Earth Sciences, Department of Hydrology and Water Management, ul. Lwowska 1, 87-100 Toruń, Poland

\begin{abstract}
The objective of this study is to determine the usefulness of results of hydrological observations (1961-2015) carried out in a deep lake for the assessment changes in the ice-thermal regime of a shallow lake. The paper is based on results of daily values of surface water temperature and ice phenomena in shallow Lake Łebsko and deep Lake Charzykowskie. Similar, statistically significant, positive trends of water temperature were determined in both lakes $\left(0.26^{\circ} \mathrm{C} 10\right.$ year ${ }^{-1}$ in Lake Łebsko and $0.25^{\circ} \mathrm{C} 10$ year ${ }^{-1}$ in $\mathrm{Lake}$ Charzykowskie). The fastest increase in mean monthly water temperature in the analysed period $(1961-2015)$ occurred in $\mathrm{May}\left(3.37^{\circ} \mathrm{C}\right.$ in Lake Charzykowskie) and April $\left(2.76^{\circ} \mathrm{C}\right.$ in Lake Łebsko). The majority of elements of the thermal regime of surface waters in shallow lakes were generally determined to be similar to the same elements in deep lakes, and the effect of climatic changes on the thermal regime of both lakes was found to be similar. Less similarity is observed between elements of the ice regime, particularly in date of decline of the ice cover.
\end{abstract}

\section{INTRODUCTION}

The most important effects of climate change on lakes of the temperate climate zone include an increase in water temperature (Woolway et al., 2017) and a reduction of ice phenomena (Benson et al., 2012). This results in the acceleration of the physical, chemical, and biological processes, and as a consequence, an increase in productivity and water trophic status. This especially applies to shallow lakes, rarely covered by permanent long-term hydrological observations. Therefore, the objective of this study is to determine the usefulness of results of hydrological observations (1961-2015) carried out in a deep lake for the assessment of changes in the icethermal regime of a shallow lake.

Abundant literature is available on the role of water temperature in the development of biotic water

Corresponding author: marszel@umk.pl

Key words: Climate warming; water temperature; ice cover; shallow lakes; deep lakes.

Edited by: Marco Toffolon, University of Trento, Italy

Received: 2 February 2018.

Accepted: 15 October 2018.

This work is licensed under a Creative Commons Attribution NonCommercial 4.0 License (CC BY-NC 4.0).

CCopyright W. Marszelewski and B. Pius, 2018

Licensee PAGEPress, Italy

J. Limnol., 2019; 78(1): 27-39

DOI: 10.4081/jlimnol.2018.1763 ecosystems. Part of the conclusions, however, are based on results of laboratory experiments, because in situ research is time-consuming, and conducted in few places (in comparison to the high number of hydrological objects) and in different climatic zones. In the zone of temperate climate, an important role of water temperature was determined among others for the rate of growth of macrophytes in shallow Lake Vechten (Best and Visser, 1987), development of the population of lake smelt (Osmerus eperlanus eperlanus $\mathrm{m}$. spirinchus Pallas.) in Lake Peipsi (Kangur et al., 2007), abundance of cyanobacteria (Gallina et al., 2011), abundance of phytoplankton in shallow Loch Leven (Elliott and Defew, 2012), on the fish community of shallow Lake Peipsi (Kangur et al., 2013) or zooplankton community in shallow Laguna Chascomús (Diovisalvi et al., 2015).

Less studies concern the effect of changes in the ice regime on lake fauna and flora. This results from the fact that the ice cover only occurs in the cool and transitional part of the zone of temperate climate, in cold climate, and in azonal (high mountain) climate. Morever, long-term research on ice cover is not conducted commonly, and gaps are often present in observation results (Vincent, 2009). In the case of shallow lakes, the most important issues include: the rate of growth of phytoplankton under the ice cover (for examples: Philips and Fawley, 2002; Ejankowski and Lenard, 2016), availability of phytoplankton for zooplankton under the ice (Campbell and Haase, 1981), and the effect of climate warming in winter seasons on the fish population (among others Sørensen et al., 2011). An extensive study referring to multiannual trends of ice phenomena and water temperature in East Europe based on the example of shallow Lake Võrtsjärv and considerably deeper Lake Peipsi was presented by Nõges and Nõges (2014). 


\section{METHODS}

This work is based on results of daily observations of air temperatures from the meteorological stations in Łeba and Chojnice, and daily observations of water temperatures and ice cover from the hydrological stations on Lake Lebsko and Lake Charzykowskie. All of the stations belong to the Institute of Meteorology and Water Management - National Research Institute. The meteorological and hydrological observations were performed every day in the years 1961-2015 at 6 a.m. GMT: first at an altitude of $200 \mathrm{~cm}$ above ground level, and second at a depth of $40 \mathrm{~cm}$. Measurement at a depth of $40 \mathrm{~cm}$ is fully representative of water surface temperature. It was confirmed already many years ago during experimental measurements conducted by the Institute of Meteorology and Water Management National Research Institute in Warsaw. The results of the observations are accurate in the period without ice or in a period with low thickness of ice. Sometimes ice thickness exceptionally exceeds $40 \mathrm{~cm}$. In such a case, water temperature measurement is performed $10 \mathrm{~cm}$ below the ice bottom surface. The water temperature at a depth of $40 \mathrm{~cm}$ does not reflect heat content throughout the lake, but only in the near-surface layer of the lake.

Trends in time series were estimated using two methods. The multiannual variability of air temperature, water temperature, and ice cover in the lakes were evaluated based on the linear regression parametric test and the Mann-Kendall non-parametric test. This method was adopted due to the limitations in applying linear regression requiring assumptions of distribution normality and values independent in a time series.

The test statistic is Kendall's sum (commonly denoted as $S$ ) divided by the square root of its variance under the hypothesis of independent and identically distributed observations. If $n$ is the length of the time series and $a_{l}$, $a_{2}, \ldots, a_{n}$ denote the time series values, then the test statistic equals

$$
\frac{1}{\sqrt{v}} S
$$

where $\mathrm{S}$

$S=\sum_{l \leq i \leq j \leq n} \operatorname{sgn}\left(a_{j}-a_{i}\right)$,

and

$v=\frac{n(n-1)(2 n+5)}{18}$

The significance level is valid under the null hypothesis of independent and identically distributed observations.

Obtaining significant results from both of the tests was assumed to be a more convincing proof of the occurring changes in air temperature, water temperature, and ice cover in a time series. If contrary results were obtained (one showing an existing trend and the other not), such a time series was considered as not showing a trend (the rule of searching for strong changes in data). The application of more than one test for the estimation of a trend is recommended (Robson et al., 2000). The extent of an increase or decrease in temperature of lake aters was estimated using coefficients of simple regression directions.

The analysis of simple regressions does not allow for fluctuations or short-term oscillations in a time series. As a result, a method of the rescaled adjusted partial sums (RAPS) of series in relation to the multiannual value was applied.

RAPS $Y_{k}=\sum_{t=1}^{k} \frac{x_{t}-\bar{x}}{\sigma_{x}} \quad k \in(1,2, \ldots n)$

where: $x_{t}$ - element of the studied series, $\bar{x}$ - mean value of the studied series, $\sigma_{x}$ - mean deviation of the series values, $\mathrm{n}$ - number of observations.

The RAPS method permits detecting trends and fluctuations in certain parts of a time series. Consequently, two fundamental sub-periods with different values of water temperature were distinguished in the analysed time series. In the years 1961-1987, temperature values were noticeably lower than in the years 1988-2015. The test of differences between means was applied in order to compare temperature differences in the distinguished subperiods. The test verified the null hypothesis of the equality of the two mean values of water temperature in the two sub-periods: 1961-1987 and 1988-2015. The Student's $t$-test for uncorrelated variables was used. Homogeneity of variances was checked by the F test.

The adopted significance level for all the analyses was $\mathrm{P}<0.05$. Pearson's correlation at the significance level of 0.05 was assumed as an indicator of the relationship between air and water temperature and ice cover. This correlation refers to linear relationship.

Based on daily values of surface water temperature, four thermal seasons (periods) were distinguished, namely winter, spring, summer, and autumn. The following phases were designated in the winter season:

- phase of winter cooling - from the date of occurrence of the ice cover to the date with minimum temperature, and

- phase of winter warming - from the moment of occurrence of minimum temperature to the date of disappearance of the ice cover. 
The following phases were designated in the spring season:

- early phase of spring warming - from the date of disappearance of the ice cover to the moment of exceeding water temperature of $4^{\circ} \mathrm{C}$, and

- late phase of spring warming - from permanent exceeding of water temperature of $4^{\circ} \mathrm{C}$ to the date of permanent exceeding of $15^{\circ} \mathrm{C}$.

The following phases were designated in the summer season:

- phase of summer warming - from the date with water temperature from $15^{\circ} \mathrm{C}$ to the date of its maximum value, and

- phase of summer cooling - from the date with maximum temperature to the moment of a permanent decrease in temperature below $15^{\circ} \mathrm{C}$.

The following phases were designated in the autumn season:

- first phase of autumn cooling - from the date of a permanent decrease in water temperature below $15^{\circ} \mathrm{C}$ to the moment of reaching $4^{\circ} \mathrm{C}$, and

- second phase of autumn cooling - from the moment of a permanent decrease in water temperature below $4^{\circ} \mathrm{C}$ to the date of appearance of the ice cover.

The designation of thermal seasons permitted the comparison of the course of water temperature in both lakes in a one-year period. Whenever a year is mentioned in this paper, it denotes the hydrological year lasting from 1 November to 31 October.

\section{RESULTS}

\section{Research area}

The studied lakes are located in the northern part of Poland, in two different geomorphological regions: the coastal lowland and the outwash plain. The coastal lowland runs along the southern shore of the Baltic Sea, has an average width of approx. $15 \mathrm{~km}$, and a height from several to approx. $20 \mathrm{~m}$ ASL. The outwash plain was formed by fluvioglacial water at the end of the last glaciation, and is located at an altitude of approx. $130 \mathrm{~m}$ asl (Fig. 1).

Two different lakes were selected for the study: coastal Lake Łebsko (lake surface $70.2 \mathrm{~km}^{2}$, maximum depth $6 \mathrm{~m}$, average depth $1.6 \mathrm{~m}$, mean inclination of lake bottom $0^{\circ} 09^{\prime}$ ) and post-glacial Lake Charzykowskie (respectively: $13.4 \mathrm{~km}^{2}, 30.5 \mathrm{~m}, 7.8 \mathrm{~m}$ and $2^{\circ} 11^{\prime}$ ). The lakes are located at a distance of approx. $90 \mathrm{~km}$ from one another. One of the characteristics of Lake Lebsko is a wide belt of vegetation in the littoral zone. In the case of Lake Charzykowskie, the littoral zone is very narrow, due to the large slope in the bottom of the lake basin.

\section{Air temperature}

Air temperature has the greatest influence on the lakes' thermal and ice regime. Mean annual (1961-2015) air temperature (MAAT) reached $9.1^{\circ} \mathrm{C}$ in Łeba and $7.9^{\circ} \mathrm{C}$ in Chojnice. In both meteorological stations, a significant and similar increase in MAAT occurred, amounting to $0.26^{\circ} \mathrm{C} 10$ years $^{-1}$ in Łeba and $0.31^{\circ} \mathrm{C} 10$ years $^{-1}$ in Chojnice. The growth became especially evident from 1988 (Fig. 2). Mean monthly air temperature (MMAT) also increased nearly every month. The greatest increase in MMAT was observed in spring and summer months, when it was the most frequently statistically significant (Tab. 1).

\section{Water temperature}

Mean annual (1961-2015) water temperature (MAWT) reached $9.2^{\circ} \mathrm{C}$ in Lake Łebsko, and $9.5^{\circ} \mathrm{C}$ in Lake Charzykowskie. In both lakes, a significant and nearly identical increase in MAWT occurred, amounting to $0.026^{\circ} \mathrm{C}_{\text {year }}{ }^{-1}$ in Lake Łebsko and $0.025^{\circ} \mathrm{C}_{\text {year }}{ }^{-1}$ in Lake Charzykowskie. The increase - as in the case of air temperature - became particularly evident from 1988 (Fig. 3). The distribution of water temperature was also similar in particular months. The smallest differences in temperature occurred in the second half of the warm half-year (August, September and October), and also in the middle of the cold half-year, especially in February (Fig. 4).

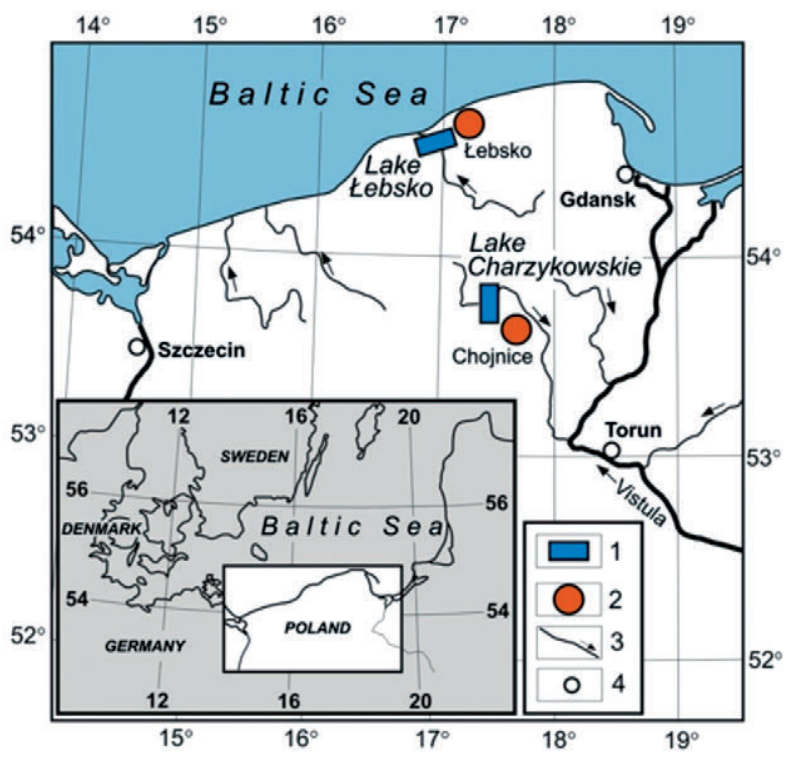

Fig. 1. Location of the research area, studied lakes, and meteorological stations. 1, analysed lakes; 2, meteorological stations; 3 , main rivers; 4 , main cities. 
Similarly to the case of air temperature, mean monthly water temperature (MMWT) also increased nearly every month. The highest increase in MMWT was observed in spring and summer months, including up to $3.37^{\circ} \mathrm{C}$ in May (Lake Charzykowskie) and $2.76^{\circ} \mathrm{C}$ in April (Lake Łebsko). Changes in water temperature in spring and summer months were statistically significant (Tabs. 2 and 3). In all the months, a statistically significant correlation was also found between air temperature and water temperature. The highest values of the correlation coefficient (in seven months above 0.85 ) occurred between air temperature in Leba and water temperature in Lake Łebsko (Tabs. 2 and 3).

A high and statistically significant correlation was also found between water temperature in both lakes (Fig. 5). The strongest relation occurs in the case of mean annual water temperature (0.82) and mean water temperature in the warm half-year $(0.81)$. The relation for mean water temperature in the cold half-year is nevertheless weaker (0.7).

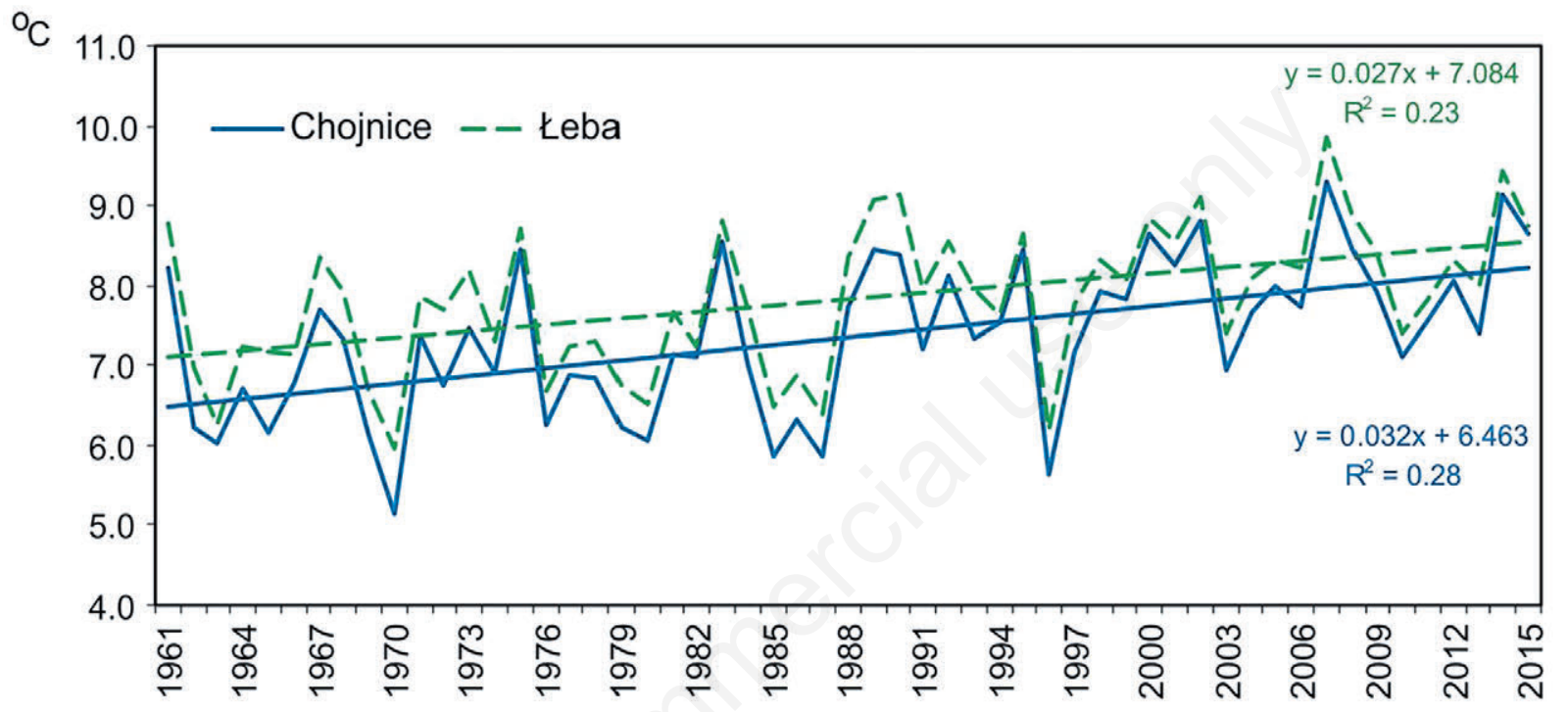

Fig. 2. The course of mean annual air temperature in Łeba and Chojnice in the years 1961-2015 with trend lines (data according to the Institute of Meteorology and Water Management of Warsaw).

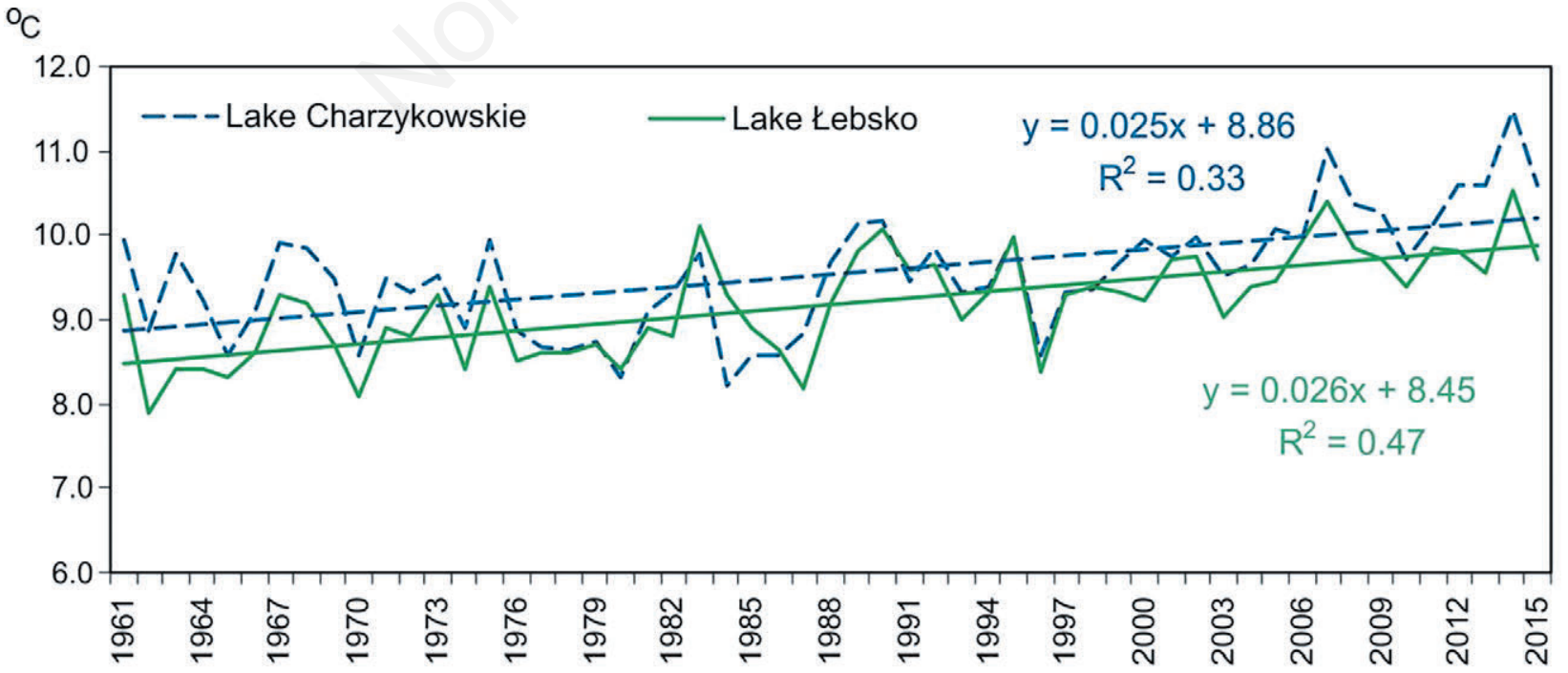

Fig. 3. The course of mean annual water temperature (MAWT) in Lake Łebsko and in Lake Charzykowskie in the years 1961-2015 with trend lines (data according to the Institute of Meteorology and Water Management of Warsaw). 


\section{Ice cover}

The ice cover developed, on average, on 24 December (median, on 26 December) on Lake Łebsko and 4 January (median, on 2 January) on Lake Charzykowskie. The disappearance of the ice cover occurred, on average, on 1 March (median, on 8 March) on Lake Lebsko and 14 March (median, 17 March) on Lake Charzykowskie. Such a significant difference in the dates of the end of the
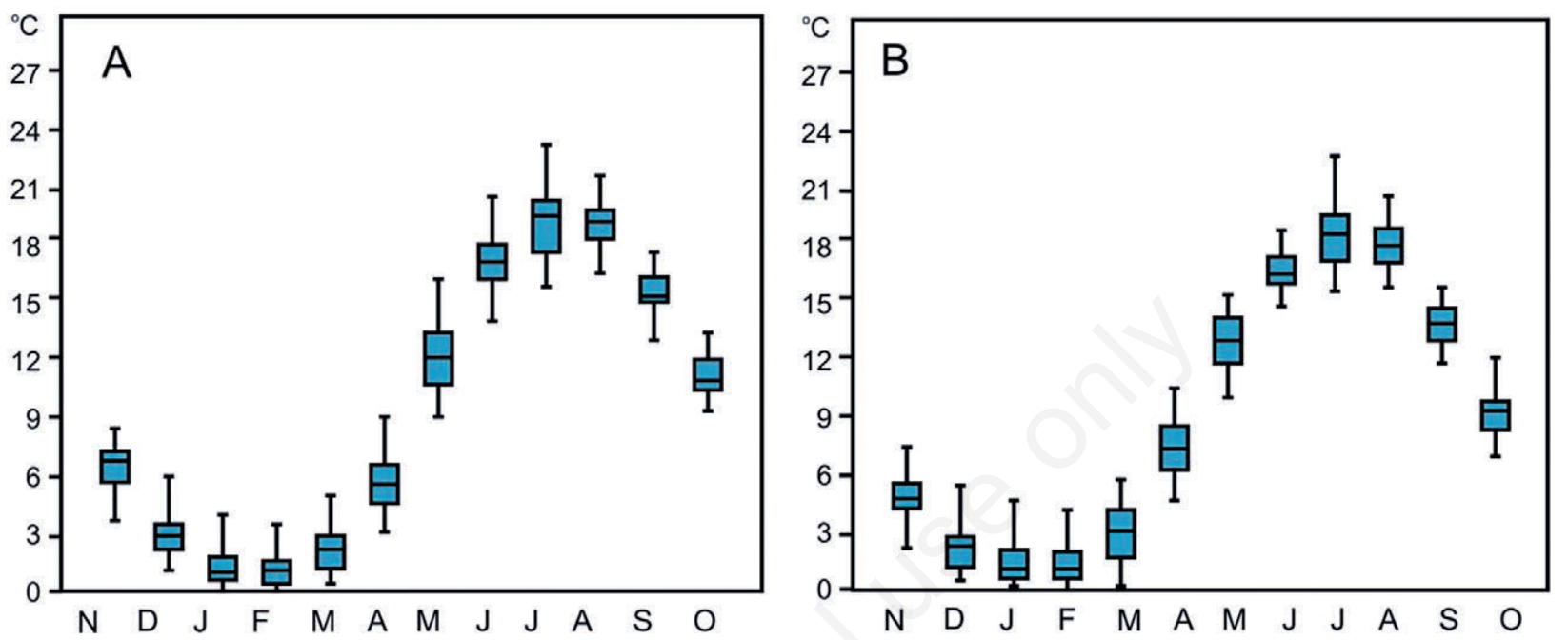

Fig. 4. Water temperature distribution in particular months (1961-2015) in Lake Lebsko (A) and in Lake Charzykowskie (B).

Tab. 1. Mean monthly air temperature in Łeba (Ł) and Chojnice (C) in the years 1961-2015 and their changes in this 55-year period. Statistically significant changes in bold.

\begin{tabular}{lcccccccccccc} 
Parameter & Nov & Dec & Jan & Feb & Mar & Apr & May & Jun & Jul & Aug & Sep & Oct \\
MMAT (Ł) & 4.5 & 0.9 & -0.6 & -0.3 & 2.2 & 6.0 & 10.6 & 14.3 & 16.9 & 16.8 & 13.5 & 9.1 \\
\hline Changes (L) & 0.66 & 1.10 & 2.01 & 1.73 & 1.58 & $\mathbf{1 . 9 6}$ & $\mathbf{1 . 9 6}$ & 0.73 & $\mathbf{1 . 9 0}$ & $\mathbf{1 . 8 3}$ & 0.65 & -0.05 \\
\hline MMAT (C) & 2.9 & $-0,8$ & -2.5 & -1.7 & 1.7 & 6.9 & 12.2 & 15.3 & 17.1 & 16.7 & 12.7 & 7.8 \\
\hline Changes (C) & 0.78 & 1.49 & 2.42 & 2.25 & $\mathbf{2 . 1 0}$ & $\mathbf{2 . 3 5}$ & 1.53 & 0.10 & $\mathbf{2 . 5 1}$ & $\mathbf{2 . 3 1}$ & 1.05 & 0.32
\end{tabular}

MMAT, mean monthly air temperature.

Tab. 2. Mean monthly water temperature in Lake Łebsko in the years 1961-2015, change in water temperature during 55 years and the correlation of air temperature in Łeba with the temperature of surface water in Lake Łebsko. Statistically significant values in bold.

\begin{tabular}{lccccccccccccc} 
Parameter & Nov & Dec & Jan & Feb & Mar & Apr & May & Jun & Jul & Aug & Sep & Oct \\
MMWT & 4.8 & 2.1 & 1.4 & 1.3 & 3.0 & 7.5 & 13.0 & 16.8 & 18.7 & 18.1 & 13.9 & 9.3 \\
\hline Changes & 0.70 & 0.97 & $\mathbf{1 . 1 4}$ & 0.70 & $\mathbf{1 . 6 7}$ & $\mathbf{2 . 7 6}$ & $\mathbf{2 . 5 9}$ & $\mathbf{0 . 7 7}$ & $\mathbf{2 . 5 3}$ & $\mathbf{2 . 1 4}$ & $\mathbf{1 . 3 2}$ & 0.33 \\
\hline Correlation AW & $\mathbf{0 . 8 7}$ & $\mathbf{0 . 7 5}$ & $\mathbf{0 . 8 0}$ & $\mathbf{0 . 8 2}$ & $\mathbf{0 . 9 2}$ & $\mathbf{0 . 8 3}$ & $\mathbf{0 . 8 7}$ & $\mathbf{0 . 8 2}$ & $\mathbf{0 . 9 3}$ & $\mathbf{0 . 8 8}$ & $\mathbf{0 . 8 8}$ & $\mathbf{0 . 9 5}$ \\
\hline
\end{tabular}

MMWT, mean monthly water temperature; $A$, air temperature; $W$, surface water temperature.

Tab. 3. Mean monthly water temperature (MMWT) in Lake Charzykowskie in the years 1961-2015, change in water temperature during 55 years and the correlation of air temperature in Chojnice with the temperature of surface water in Lake Charzykowskie. Statistically significant values in bold.

\begin{tabular}{lcccccccccccc} 
Parameter & Nov & Dec & Jan & Feb & Mar & Apr & May & Jun & Jul & Aug & Sep & Oct \\
MMWT & 6.5 & 2.9 & 1.3 & 1.1 & 2.1 & 5.7 & 12.3 & 17.2 & 19.3 & 19.2 & 15.6 & 11.2 \\
\hline Changes & -0.28 & 0.97 & 1.17 & 0.89 & $\mathbf{1 . 7 1}$ & $\mathbf{2 . 5 2}$ & $\mathbf{3 . 3 7}$ & 0.76 & $\mathbf{1 . 7 9}$ & $\mathbf{2 . 0 2}$ & 0.99 & 0.35 \\
\hline Correlation AW & $\mathbf{0 . 7 2}$ & $\mathbf{0 . 6 2}$ & $\mathbf{0 . 6 7}$ & $\mathbf{0 . 8 0}$ & $\mathbf{0 . 7 6}$ & $\mathbf{0 . 6 7}$ & $\mathbf{0 . 7 6}$ & $\mathbf{0 . 7 6}$ & $\mathbf{0 . 8 9}$ & $\mathbf{0 . 8 5}$ & $\mathbf{0 . 8 3}$ & $\mathbf{0 . 6 9}$
\end{tabular}

$M M W T$, mean monthly water temperature; $A$, air temperature; $W$, surface water temperature. 
occurrence of ice cover is connected with its complete inexistence on Lake Charzykowskie in the years of 1988 , 1990, 2007, and 2008 (Fig. 6). In the same years, a (thin) ice cover was observed on Lake Łebsko for a very short period of time (only several days). This significantly affected the different times of disappearance of the ice

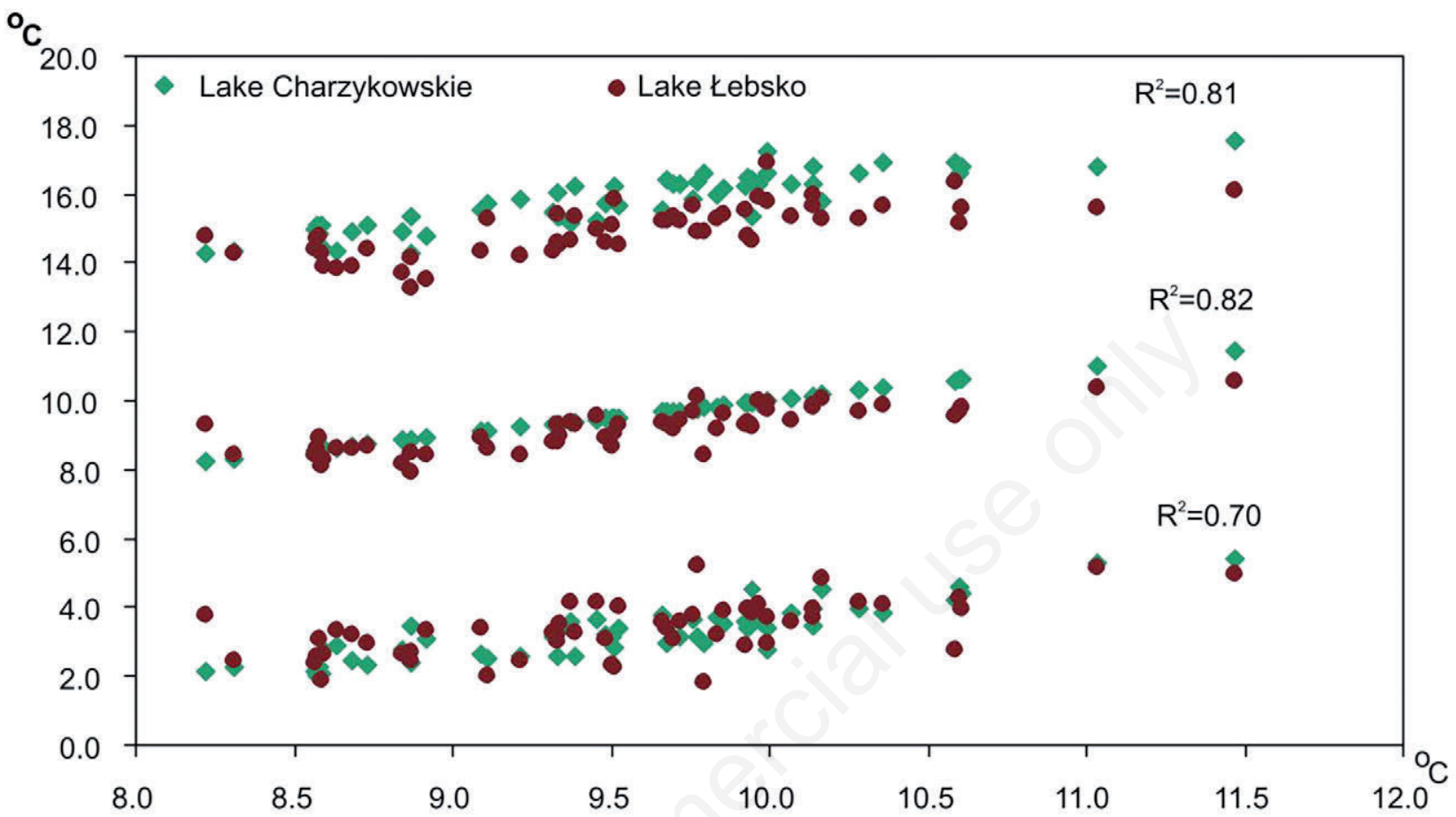

Fig. 5. Correlation between water temperatures in lakes Łebsko and Charzykowskie in the years 1961-2015. Upper, mean value in the warm half-year; middle, annual mean value; lower, mean value in the cold half-year.

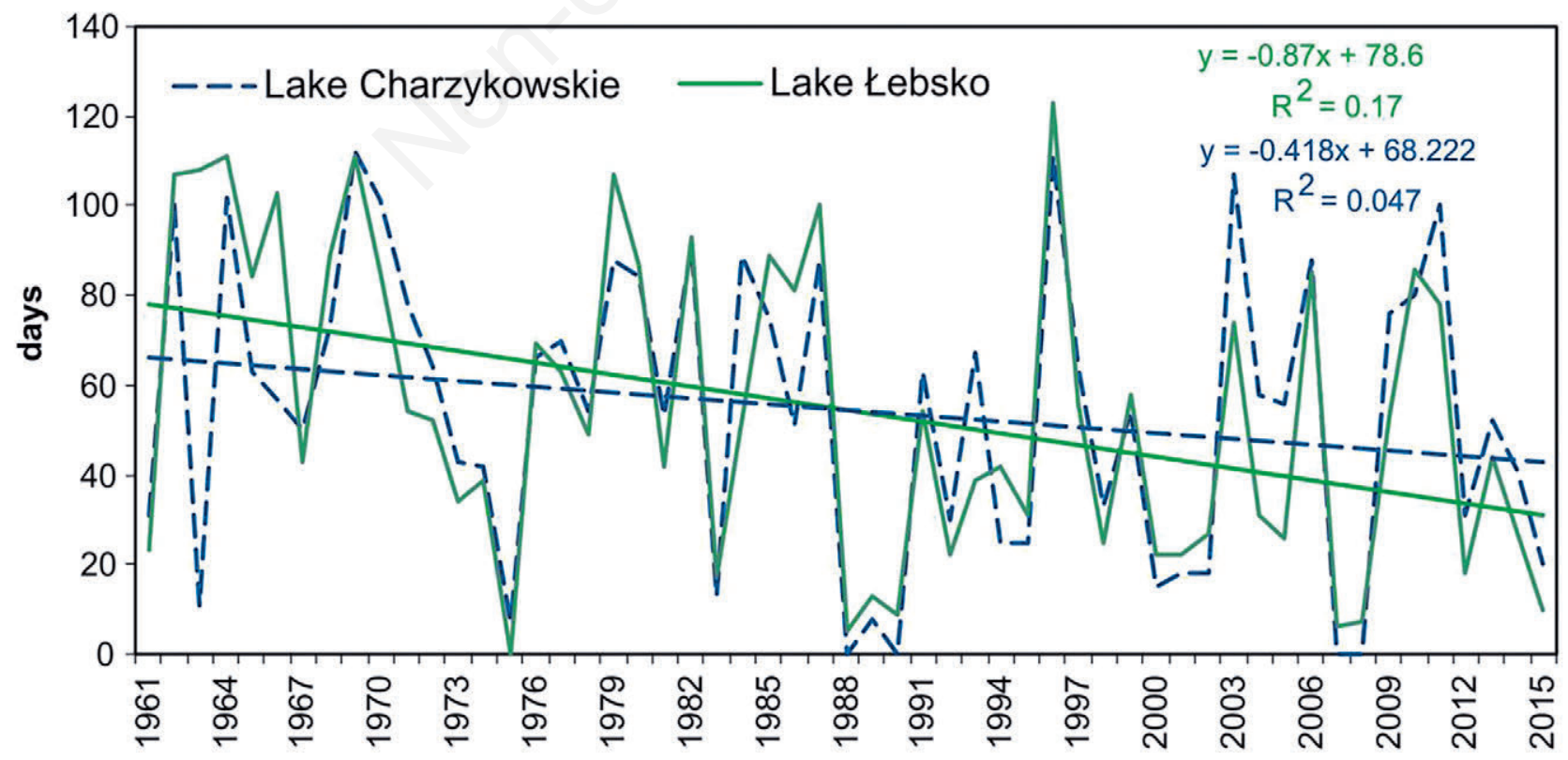

Fig. 6. Number of days of ice cover winter seasons (1961-2015) with trend lines. 
cover on both lakes. The probability of dates of freezing as well as the probability of dates of melting is different in both lakes. It is evident that the ice cover develops earlier on the shallow Lake Łebsko (Fig. 7 and Tabs. 4 and 5). A similar situation is observed in the case of unfreezing of lakes. In the case of dates with a probability of more than $50 \%$, however, the differences are not substantial due to the climatic conditions (spring thaw, solar radiation, etc.).

The ice cover persisted, on average, for 54 days during one cold season. In the period of 1961-2015, the average duration of the ice cover experienced a reduction of up to 47 days on Lake Łebsko (this change is statistically significant at a level of 0.05 ) and 23 days on Lake Charzykowskie (this change is not statistically significant). The rate of reduction of the ice cover period was, on average, 0.85 day year $^{-1}$ (Lake Łebsko) and 0.42 day year $^{-1}$ (Lake Charzykowskie).

The average maximum ice cover thickness was similar in both of the studied lakes, reaching $22 \mathrm{~cm}$ on Lake Łebsko and $23 \mathrm{~cm}$ on Lake Charzykowskie. The ice thickness was, however, varied among winters (Fig. 8). Its maximum values reached $57 \mathrm{~cm}$ on Lake Charzykowskie in 1997, and $52 \mathrm{~cm}$ on Lake Lebsko in 1980. The rate of reduction of the ice cover maximum thickness averaged $0.20 \mathrm{~cm} \mathrm{year}^{-1}$ (Lake Lebsko) and 0.18 $\mathrm{cm}_{\text {year }}^{-1}$ (Lake Charzykowskie).

Tab. 4. Probability (P) of dates of freezing.

\begin{tabular}{lccc}
$\mathbf{P}(\%)$ & Lake Lebsko & Lake Charzykowskie & Difference (days) \\
\hline 5 & $20 \mathrm{Nov}$ & $9 \mathrm{Dec}$ & 20 \\
\hline 25 & $10 \mathrm{Dec}$ & $20 \mathrm{Dec}$ & 10 \\
\hline 50 & $24 \mathrm{Dec}$ & $4 \mathrm{Jan}$ & 11 \\
\hline 75 & $5 \mathrm{Jan}$ & $21 \mathrm{Jan}$ & 16 \\
\hline 90 & $28 \mathrm{Jan}$ & $15 \mathrm{Feb}$ & 18
\end{tabular}

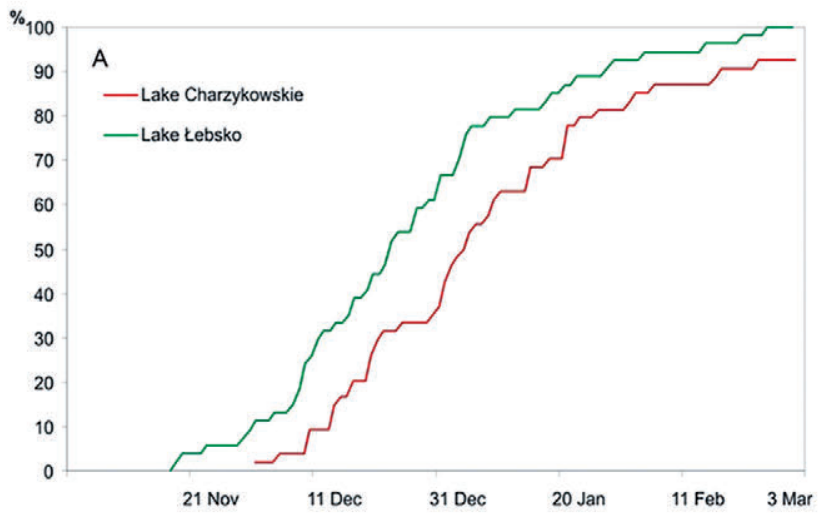

\section{DISCUSSION}

The analysed lakes differ greatly in date of both the origins and the morphometric conditions. In addition, the dynamics of water masses are completely different in shallow polimictic Lake Łebsko in comparison to deep dimictic Lake Charzykowskie. Both lakes, however, are affected by similar weather conditions, which, to the greatest extent, shape their thermal and ice regime. In such a situation, the question arises, whether the impact of the changing weather conditions on the thermal and ice system of both lakes is similar or not. It appears that the majority of the characteristics of the thermal system are similar, and subject to similar changes in both lakes. This is supported by, among others, a strong correlation between mean annual water temperature in both lakes and mean water temperature in the warm half-year, as well as the rate of growth in water temperature in the period of climate changes.

The existence of a strong relationship between changes in air temperature and water temperature in the lakes has been observed previously (Dąbrowski et al., 2004). However, only in 1988, a positive trend in air temperature began, and as a result, the same occurred with water temperature. The phenomenon is confirmed by the cumulative curves for mean annual air temperature and mean annual water temperature (Fig. 9). In the first part

Tab. 5. Probability $(\mathrm{P})$ of dates of melting.

\begin{tabular}{lccc}
$\mathbf{P}(\%)$ & Lake Lebsko & Lake Charzakowskie & Difference (days) \\
\hline 5 & $9 \mathrm{Jan}$ & $9 \mathrm{Feb}$ & 31 \\
\hline 25 & $14 \mathrm{Feb}$ & $28 \mathrm{Feb}$ & 14 \\
\hline 50 & $8 \mathrm{Mar}$ & $15 \mathrm{Mar}$ & 7 \\
\hline 75 & $21 \mathrm{Mar}$ & $29 \mathrm{Mar}$ & 8 \\
\hline 90 & $1 \mathrm{Apr}$ & $7 \mathrm{Apr}$ & 6
\end{tabular}

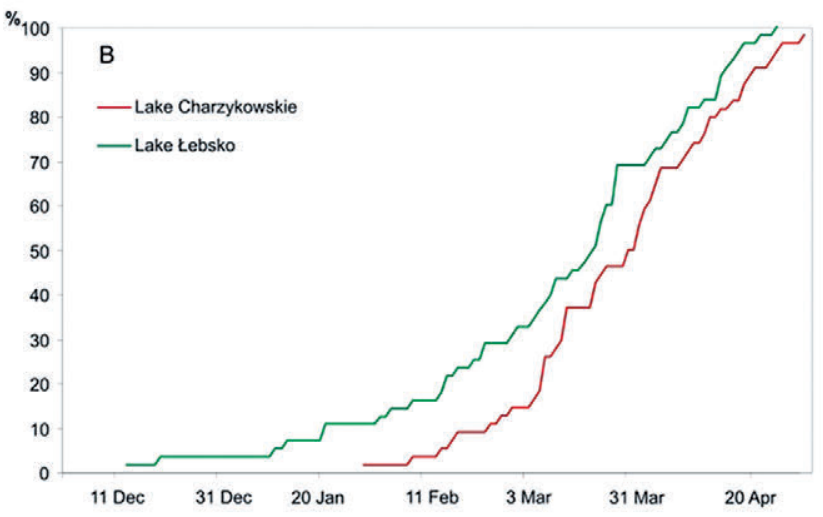

Fig. 7. Accumulated curves of freezing (A) and melting (B) of ice cover. 
of the analysed period (1961-1987) in Lake Łebsko, mean annual water temperature was $8.8^{\circ} \mathrm{C}$, and in the second (1988-2015) $9.6^{\circ} \mathrm{C}$. Water temperature in Lake Charzykowskie developed similarly in both periods in which it amounted to $9.1{ }^{\circ} \mathrm{C}$ and $10.0^{\circ} \mathrm{C}$, respectively.

The confirmation of the considerable acceleration of the rate of water temperature increase from 1988 is also an increase in the number of days in a year with high $\left(>21^{\circ} \mathrm{C}\right)$ temperature, and a decrease in the number of days with low temperature $\left(<1^{\circ} \mathrm{C}\right)$. Both the aforementioned phenomena are statistically significant. In Lake Łebsko, where in the period 1961-2015 an average of 54 days with temperature of $>21^{\circ} \mathrm{C}$ occurred, from 1988, positive deviations from the mean value exceeding even 30 days in a year are characteristic. In Lake Charzykowskie, where the number of days with temperature of $>21^{\circ} \mathrm{C}$ averaged 49 in the period 1961 2015, an increase in the number of days with such high temperature was even greater, and exceeded 40 in 1994 and 2014 (Fig. 10). The total number of days in a year

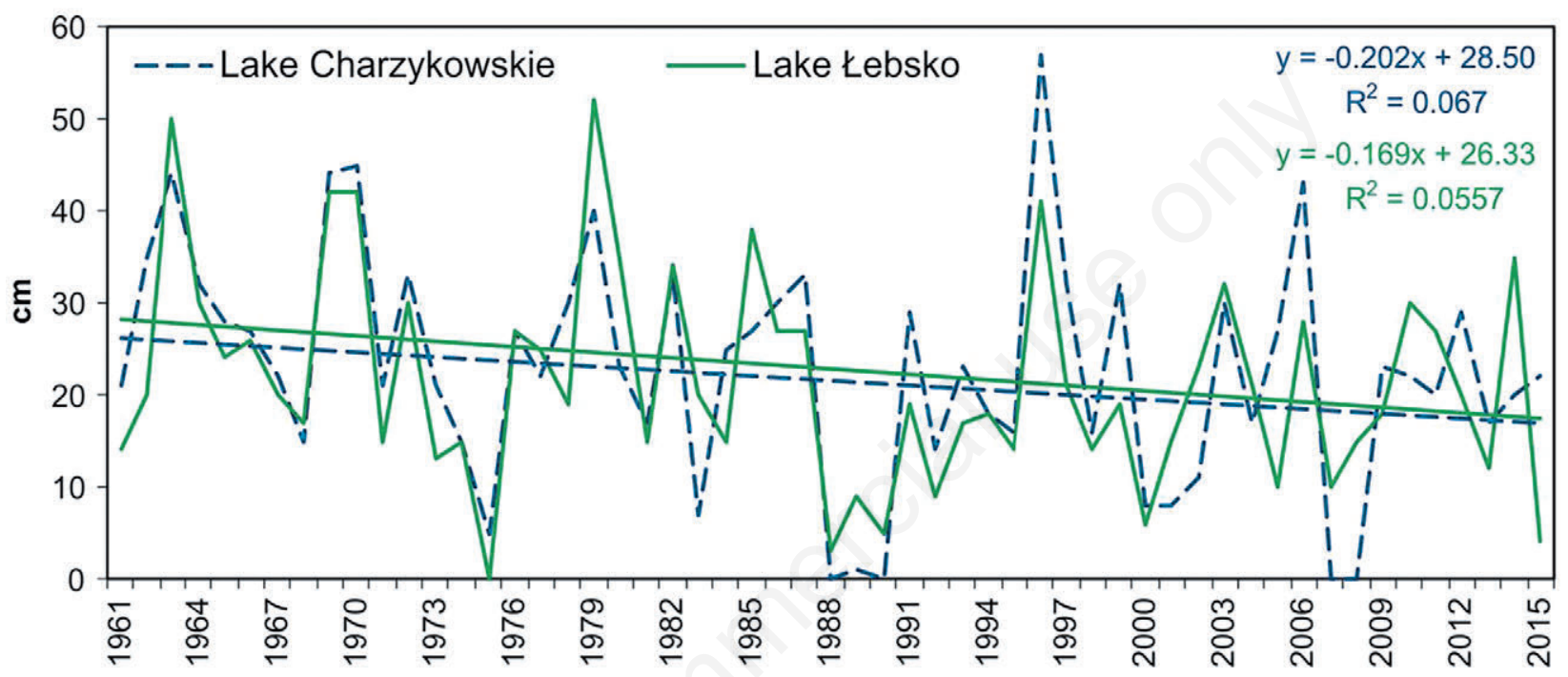

Fig. 8. Variability of the maximum thickness of the ice cover in the years 1961-2015.

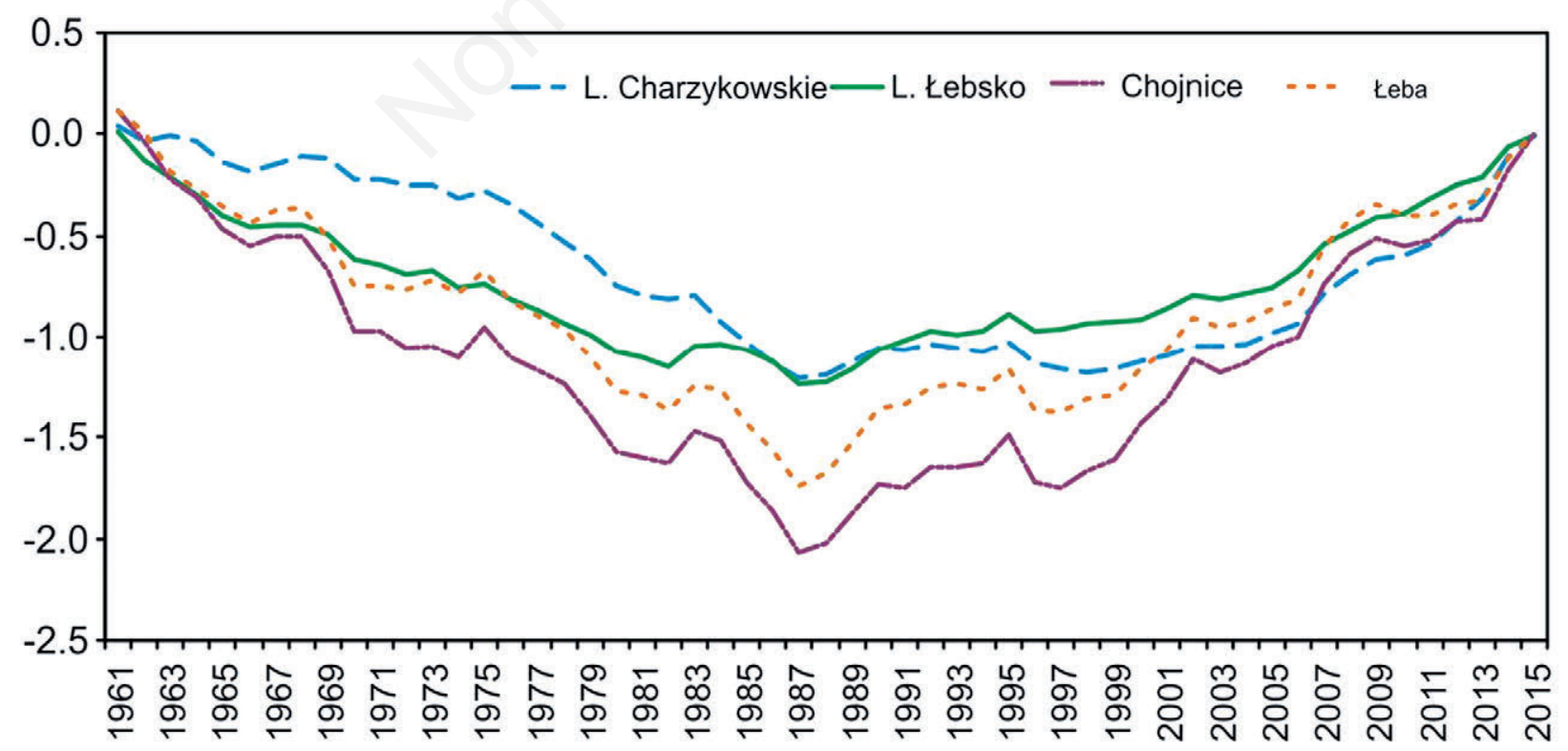

Fig. 9. Cumulative curves of air temperature and water temperature. 
with low water temperature $\left(<1^{\circ} \mathrm{C}\right)$ is subject to a considerable decrease (in some years by more than 30 days in Lake Łebsko, and more than 40 days in Lake Charzykowskie, Fig. 11).

The course of the mean daily (1961-2015) water temperature in a year in both analysed lakes is similar. Slight differences in the course result from the natural properties of the lakes, including particularly different volumes and water dynamics. Water temperature in Lake Łebsko is generally less stable in short periods of time, i.e. it is subject to short-term slight increases and decreases. In such date, the temperature of Lake Charzykowskie is more stable, which is particularly determined by high volume of the epilimnion. Moreover, water in shallow Lake Lebsko cools faster in autumn in comparison to Lake Charzykowskie, and is higher in spring and again lower in summer (Fig. 12). Differences in water temperature are insubstantial, and usually amount to approximately $1{ }^{\circ} \mathrm{C}$. Only in the winter season water temperature is the same in both lakes.

The differences between surface water temperature in both lakes permitted the designation of four different thermal seasons, and in each thermal season two additional phases (the methodology of their designation was specified in the second part of this paper). The duration of two thermal seasons is similar in both lakes. The autumn season lasts 104 days in both lakes, and the summer season 108 (in Lake Łebsko) and 118 (in Lake Charzykowskie). The winter season in Lake Lebsko is almost half shorter than in Lake Charzykowskie, and the summer season is half longer (Fig. 12). Shorter winter season in Lake Lebsko is probably related to the warming effect of the Baltic Sea, also resulting in the prolongation of the duration of the spring season. It seems that the determination of the duration of thermal seasons in the lakes is facilitated by the comparison of their thermal regime, including particularly water temperature during a year. This, however, concerns lakes located in the same climate zone, including particularly lakes in the temperate zone, where lakes are characterised by the highest water mass dynamics.

Greater differences were found between the analysed features of the ice cover system, especially in the case of the beginning and ending of its occurrence. Such differences are particularly evident in mild winters during which thin ice occurs on shallow lakes, whereas in the

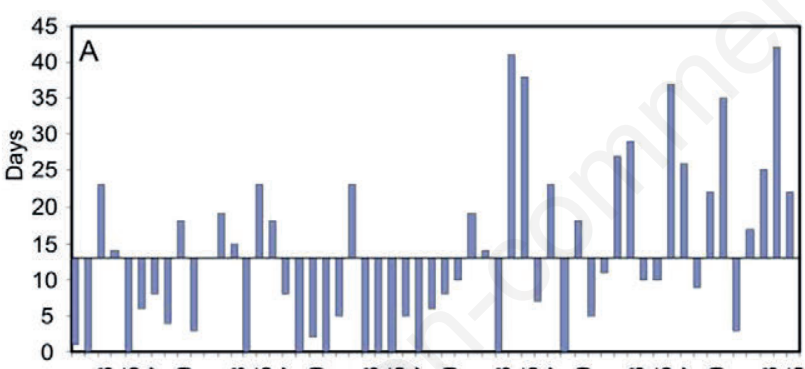

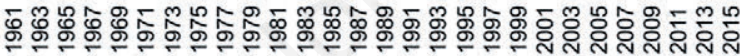

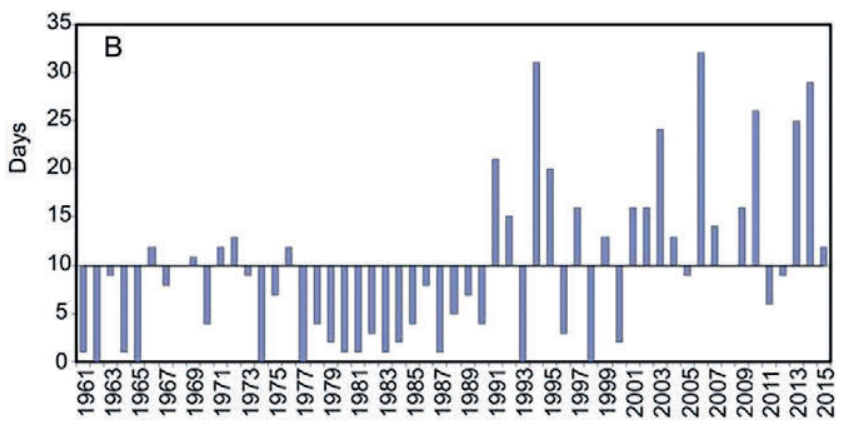

Fig. 10. Deviations of the total number of days in a year with water temperature of $>21^{\circ} \mathrm{C}$ from the mean value from the period 1961 2015 in Lake Lebsko (A) and Lake Charzykowskie (B).

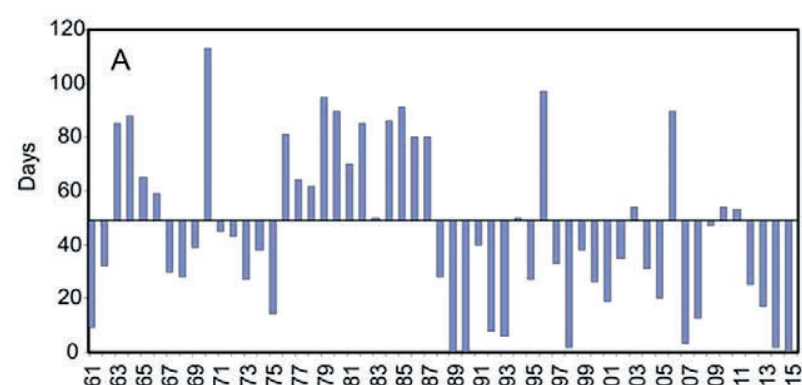

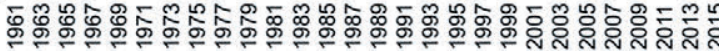

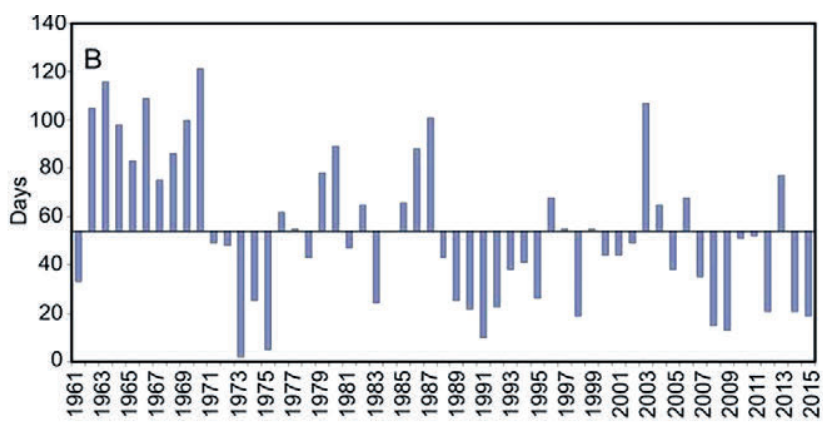

Fig. 11. Deviations of the total number of days in a year with water temperature of $<1^{\circ} \mathrm{C}$ from the mean value from the period 1961 2015 in Lake Łebsko (left) and Lake Charzkowskie (B). 
deep ones it does not occur at all. This results from the different amounts of heat accumulated in lake water at different depths. Considering the fact that in recent years mild winters have been observed more often, this problem may be more evident in the near future. The rate of reduction of the ice cap's persistence was also determined to differ in the lakes. It is twice faster in the shallow lake (Lebsko) in comparison with the deep lake. In both lakes, similar maximum ice cap thicknesses occurred, although in different winter seasons.

The strong trend in ice thickness in both lakes is related both to air temperature increase in the winter season and a considerably smaller role of snow accumulation in comparison to the northern part of Europe (Leppäranta, 2015), or lakes with large surface areas (Kouraev et al., 2008). The average number of days with snow cover in the years 1970-2000 was 58 in the vicinity of Lake Charzykowskie, and 46 in the vicinity of Lake Łebsko, with a tendency decreasing to approx. (respectively) 47 and 37 days in the years 2005-2015. The mean snow cover depth in the years 1970-2000 was $9 \mathrm{~cm}$, and in the period 2005-2015 only $7 \mathrm{~cm}$. Moreover, over the last 30 winter seasons, snow cover rarely persisted continuously on the ice, because winter thaws were increasingly frequent. Due to the above reasons, a strong trend in ice thickness could occur and be documented.

There are many other factors determining freezing and unfreezing of lakes. Freezing of lakes depends among others on the value of heat transport from the warm deeper layers to the lake surface, and the timing of freezing is strongly dependent on synoptic conditions, passages of cold air masses, and strong wind over the lake. During melting of ice, solar radiation is the dominant source of heat for ice and snow, partly absorbed by the ice cover and partly by the lake water below (Kirillin et al., 2012). Moreover, the albedo and transparency of ice have a strong influence on melting (Leppäranta 2015). The key role of the solar radiation also explains the fact that ice breakup date is coherent at spatial scales of hundreds of kilometres (Magnuson et al., 2000; Shuter et al., 2013). Also in the case of the largest lakes (for example Lake Ladoga), the ice regime depends on heat losses through the surface, lake morphometry, and wind conditions (Karetnikov et al., 2017). In spite of so many different factors, air temperature has a stronger effect on ice covers than lake characteristics alone can trigger (Bernhardt et al., 2012).

The comparison of the course of ice phenomena in a shallow (polymictic Lake Müggelsee) and deep lake (dimictic Lake Stechlin) was performed earlier in the Berlin-Brandenburg region (Bernhardt et al., 2012). The lakes are located at a distance of approximately $650 \mathrm{~km}$ west of Lakes Charzykowskie and Łebsko. A correlation was determined between the occurrence of ice phenomena and depth of lakes, with the application of the Flake model. In the case of deep lakes, shorter ice-covered periods, later freezing dates, and more ice-free winters were determined than in shallow lakes. The same phenomena were observed in the case of deep Lake Charzykowskie in comparison to shallow Lake Lebsko. Due to the higher heat content, the ice cover on deep lakes develops later (Lake Charzykowskie - on average on

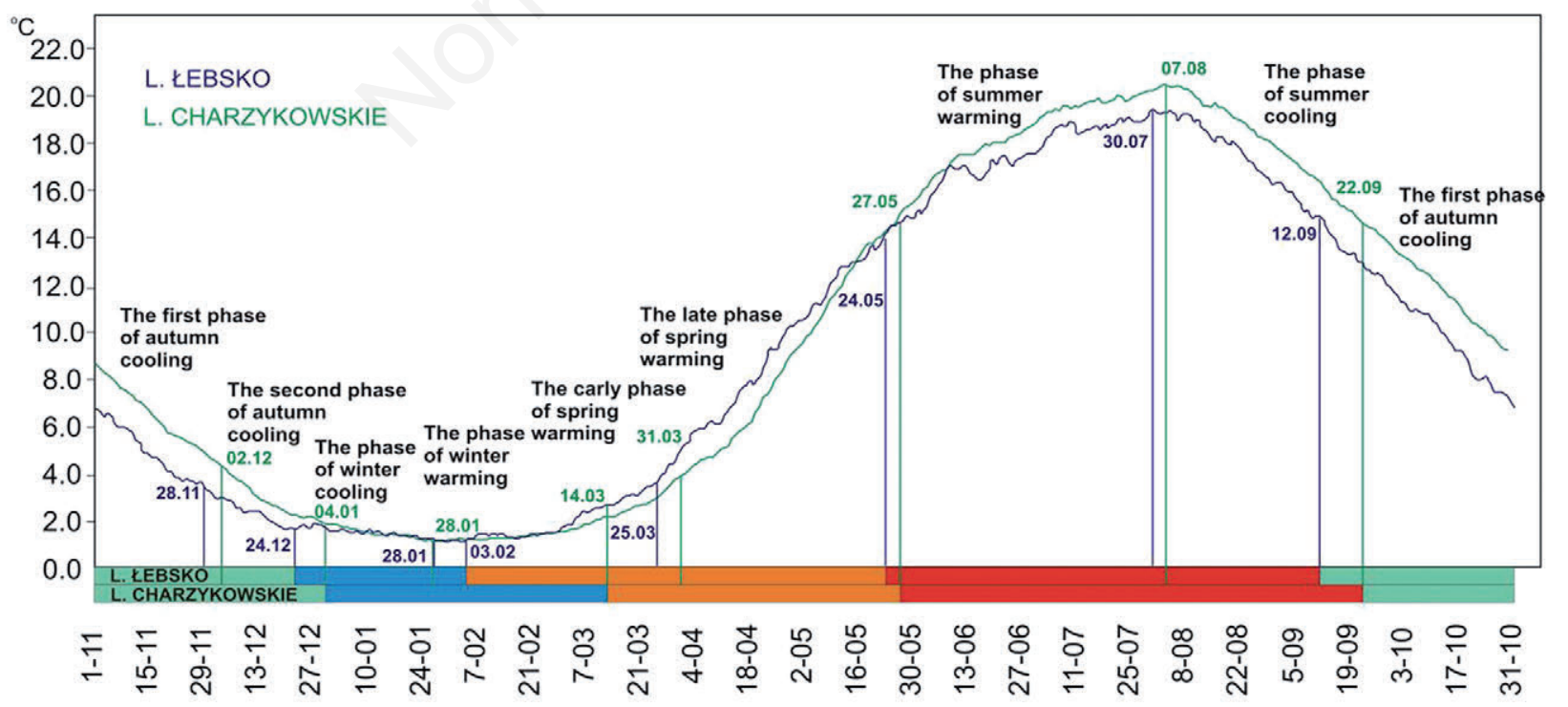

Fig. 12. Thermal seasons in Lake Łebsko and Lake Charzykowskie on the background of the course of mean daily (1961-2015) water temperature. Green, autumn season; blue, winter season; orange, spring season; red, summer season. 
January 4, Lake Stechlin - on average on February 14) than in shallow lakes (Lake Łebsko - on average on December 24, Müggelsee - on average on December 30). Later freezing of lakes in the Berlin-Brandenburg region is related to higher air temperature in the winter season, and greater influence of warmer air masses from over the Atlantic Ocean. The phenomena confirm the occurrence of the latitudinal dependency of ice climatology. Earlier, based on the example of lake from north-east Germany, in the northern part of Poland and Lithuania, they were documented by Marszelewski and Skowron (2005). Deep and shallow lakes in north-east Germany, as well as in north Poland, are also similar in terms of trends in ice phenology. Significant differences only concern the percentage of winters without ice cover on lakes. Deep Lake Stechlin was ice-covered only up to $30 \%$ in the winters of 1947-2007 (Bernhardt et al., 2012), and the index for deep Lake Charzykowskie is 93\%. This is related to climatic differences, as mentioned earlier.

The justification of the comparison of the thermal and ice regime of a deep and shallow lake is confirmed by results of earlier studies on 11 lakes performed in the state of Wisconsin (USA). The research covered 61 limnological parameters most directly influenced by climatic processes (Kratz et al., 1998). It was determined that water temperature and ice cover in all lakes were highly coherent, and especially epilimnetic temperature during summer (coherence 0.91). The least coherence (only 0.34) was found for hypolimnetic temperature. Results of the study show that surface parameters are more closely linked to climatic factors than are subsurface physics. The main forces affecting thermal regime throughout lakes during winter are discussed by Kirillin et al. (2012). According to the authors, processes and phenomena responsible for water stratification or mixing below ice-cover include among others: seiches, shear mixing, density currents, heat flow from sediments, surface inflow beneath the ice, convective mixing, and solar radiation. Solar radiation is of the highest importance at the end of the period with ice cover on lakes. Due to the above, it should be emphasised that results of our study are representative exclusively of surface water layer in both lakes.

Results of research on the thermal regime and ice regime of deep and shallow lakes shows high probability of their occurrence in both types of lakes. It is interesting that the similarity occurs in spite of completely different parameters of the lakes: morphometric, physical (including those related to water dynamics), chemical, and biological. This is confirmed by the inter-annual coherence between lakes on ice-on and ice-off dates in relation to the longitudinal distance between lakes around the northern hemisphere - at a distance of $1^{\circ}$ geographical longitude it equals $\mathrm{r}^{2}=0.75$ (Magnuson et al., 2004). The importance of different phenomena and physical processes for lakes during the occurrence of ice cover was discussed by Kirillin et al. (2012). They designated three winter phases in lakes, and drew attention to among others the role of snow and solar radiation during ice break-up.

Our paper focuses on evidencing that air temperature determines water temperature in two very different lakes (in terms of morphometry and water dynamics) in a similar way. Similar conclusions from other areas are presented by among others Bernhardt et al. (2012), Magnuson et al. (2004), or Kratz et al. (1998). A new element is among others the determination of thermal seasons for the lakes, and comparison of their duration. Moreover, a strong trend in ice thickness in both lakes was emphasised. It is a rarely discussed characteristic of ice phenomena.

The study of thermal and ice regime is important to determine the actual conditions of functioning of lake ecosystems in the temperate climate zone (Livingston et al., 2010; Weyhenmeyer et al., 2011; Dokulil, 2014). The occurrence of the ice cover slows down the majority of processes taking place in the lake during winter. In the case of absence of ice cover, the range of light in the lake increases, followed by an increase in oxygen concentration and amount of nutrients. The growth of water temperature increases the productivity of the lake. Such phenomena and processes are important for both abiotic and biotic characteristics of lakes.

\section{CONCLUSIONS}

The study results presented in this paper show that the majority of elements of the thermal regime of surface water in shallow lakes is similar to the same elements in deep lakes. Therefore, effects of climate changes in the thermal regime of both types of lakes are similar. This is confirmed by statistically significant correlations between components of the thermal regime, as well as by the periods of thermal seasons. It is worth emphasizing that the majority of thermal seasons in both lakes begin and end in similar date, and the differences amount to only several to up to a maximum of 11 days.

Lower degree of similarity occurs between elements of the ice regime, particularly in the case of the term of disappearance of the ice cover. Moreover, the rate of reduction of the ice cover period was, on average, twice faster in Lake Lebsko in comparison with Lake Charzykowskie.

In the case of lack of data on the thermal-ice regime of for shallow lakes, the majority of data from deep lakes can be implemented under the condition that they feature similar physical-geographic conditions. Moreover, they can be useful in fishery economy, as well as in planning of the use of lakes for recreational and sports purposes (particularly including winter sports). 
In this part of Europe, systematic hydrological observations of shallow lakes are rare. Due to this, it seems that it is worth comparing the thermal and ice regime of a deep and shallow lake. Earlier, by means of other methods, this was done for only two lakes (deep and shallow) in north-east Germany (Bernhardt et al. 2012). Our article presents analysis covering only two lakes (deep and shallow). Unfortunately, no more cases exist in the territory of Poland in which two neighbouring different lakes (deep and shallow) would be subject to systematic hydrological observations.

Results presented in this paper justify attempts to transpose the results of research on the thermal-ice regime from monitored lakes to lakes with no observation stations. This type of attempts has not been undertaken so far. It is therefore interesting whether similar patterns also occur in other regions and climate zones.

\section{ACKNOWLEDGMENTS}

This work was supported by the National Centre for Research and Development of Warsaw (Poland) through the ERALECC project (ERA.Net RUS Plus; ID 226).

\section{REFERENCES}

Bernhardt J, Engelhardt C, Kirillin G, Matschullat J, 2012. Lake ice phenology in Berlin-Brandenburg from 1947-2007: observations and model hindcasts. Climate Change 112:791817.

Benson BJ, Magnuson JJ, Jensen OP, Card VM, Hodgkins G, Korhonen J, Livingstone DM, Stewart KM, Weyhenmeyer GA, Granin NG, 2012. Extreme events, trends, and variability in Northern Hemisphere lake-ice phenology (1855-2005), 2012. Climatic Change 112:299-323.

Best EPH, Visser HWC, 1987. Seasonal growth of the submerged macrophyte Ceratophyllum demersum L. in mesotrophic Lake Vechten in relation to insolation, temperature and reserve carbohydrates. Hydrobiologia 148:231-243.

Campbell JM, Haase BL, 1981. Availability of suitable phytoplanktonic food for zooplankton in an ice-covered lake. Hydrobiologia 79:113-119.

Dąbrowski M, Marszelewski W, Skowron R, 2004. The trends and dependencies between air and water temperatures in lake in northern Poland from 1961-2000. Hydrol. Earth Syst. Sci. 8:79-87.

Diovisalvi N, Echeverry GES, Lagomarsino L, Zagarese HE, 2015. Seasonal patterns and responses to an extreme climate event of rotifers community in a shallow eutrophic Pampean lake. Hydrobiologia 752:125-137.

Dokulil MT, 2014. Impact of climate warming on European inland waters. Inland Waters 4:27-40.

Ejankowski W, Ekerd T, 2016. The effect of ice phenology exerted on submerged macrophytes through physicochemical parameters and the phytoplankton abundance. J. Limnol. 75:145-155.
Elliott JA, Defew L, 2012. Modelling the response of phytoplankton in a shallow lake (Loch Leven, UK) to changes in lake retention time and water temperature. Hydrobiologia 681:105-116.

Gallina N, Anneville O, Beniston M, 2011. Impacts of extreme air temperatures on cyanobacteria in five deep peri-Alpine lakes. J. Limnol. 70:186-196.

Kangur A, Kangur P, Kangur K, Möls T, 2007. The role of temperature in the population dynamics of smelt Osmerus eperlanus eperlanus $\mathrm{m}$. spirinchus Pallas in Lake Peipsi (Estonia/Russia). Hydrobiologia 584:433-441.

Kangur K, Kangur P, Ginter K, Orru K, Haldna M, Möls T, Kangur A, 2013. Long-Term Effects of Extreme Weather Events and Eutrophication on the Fish Community of Shallow Lake Peipsi (Estonia/Russia). J. Limnol. 72:376387.

Karetnikov S, Leppäranta M, Montonen A, 2017. Time series over 100 years of the ice season on Lake Ladoga. Journal of Great Lakes Research 43:979-988.

Kirillin G, Leppäranta M, Terzhevik A, Granin N, Bernhardt J, Engelhardt C, Efremova T, Golosov S, Palshin N, Sherstyankin P, Zdorovennova G, Zdorovennov R, 2012. Physics of seasonally ice-covered lakes: a review. Aquatic Sciences 74:659-682.

Kouraev AV, Shimaraev MN, Buharizin PI, Naumenko MA, Crétaux JF, Mognard N, Legrésy B, Rémy F, 2008. Ice and snow cover of continental water bodies from simultaneous radar altimetry and radiometry observations. Surveys in Geophysics 29:271-295.

Kratz TK, Soranno PA, Baines SB, Benson BJ, Magnuson JJ, Frost TM, Lathrop RC,1998. Interannual synchronous dynamics in north temperate lakes in Wisconsin, USA, p. 273-287. In: D.G. George, J.G. Jones, C.S. Puncochar, C.S. Reynolds and D.W. Sutcliffe (eds.) Management of lakes and reservoirs during global change. Kluwer, Dordrecht.

Leppäranta M, 2015. Freezing of lakes and the evolution of their ice cover. Springer, Dordrecht.

Livingston DM, Adrian R, Blenckner T, George G, Weyhenmeyer GA, 2010. Lake ice phenology, p. 51-61. In: G. Glen (ed.) The impact of climate change on European lakes. Springer, Dordrecht.

Magnuson JJ, Robertson DM, Benson BJ, Wynne RH, Livingstone DM, Arai T, Assel RA, Barry RG, Card V, Kuusisto E, Granin NG, Prowse TD, Stewart KM, Vuglinski VS, 2000. Historical trends in lake and river ice cover in the Northern Hemisphere. Science 289:1743-1746.

Magnuson JJ, Benson BB, Kratz TK, 2004. Patterns of coherent dynamics within and between lake districts at local to intercontinental scales. Boreal Environ. Res.9:359-369.

Marszelewski W, Skowron R, 2005. Spatial diversity of the ice cover on the lakes of the European Lowland in the winter season 2003/2004. Limnol. Rev. 5:155-165.

Nõges P, Nõges T, 2014. Weak trends in ice phenology of Estonian large lakes despite significant warming trends. Hydrobiologia 731:5-18.

Philips KA, Fawley MW, 2002. Winter phytoplankton community structure in three shallow temperate lakes during ice cover. Hydrobiologia 470:97-113.

Robson A, Bardossy A, Jones D, Kundzewicz ZW, 2000. Statistical methods for testing for change, p. 49-85. In: Z.W. Kundzewicz 
and A. Robson (eds.) Detecting trend and other changes in hydrological data. World Climate Programme, Geneva.

Sørensen T, Mulderij G, Søndergaard M, Lauridsen TL, Liboriussen L, Brucet S, Jeppesen E, 2011. Winter ecology of shallow lakes: strongest effect of fish on water clarity at high nutrient levels. Hydrobiologia 664:147-162.

Vincent WF, 2009. Effects of climate changes on lakes, p. 5560. In: G.E. Likens (ed.) Encyclopedia of inland waters. Elsevier, Amsterdam.
Weyhenmeyer GA, Livingstone DM, Meili M, Jensen O, Benson B, Magnuson JJ, 2011. Large geographical differences in the sensitivity of ice-covered lakes and rivers in the Northern Hemisphere to temperature changes. Global Change Biol. 17:268-275.

Woolway RS, Dokulil MT, Marszelewski W, Schmid M, Bouffard D, Merchant CJ, 2017. Warming of Central European lakes and their response to the 1980 s climate regime shift. Climatic Change 142:505-520. 